\title{
Effect of Saponin Fraction from Platycodon grandiflorum on Clinical Chemical Changes in TCDD (2,3,7,8-Tetrachlorodibenzo- $\rho$-dioxin)-induced Rat Toxicity
}

\author{
Yi-Seong Kwak ${ }^{1, *}$, You-Jin Moon ${ }^{1, *}$, Jong-Soo Kyung ${ }^{1, * *}$, \\ Tae-Hwan Kim ${ }^{2, * *}$ and Man Hee Rhee ${ }^{2, ; ; * *}$ \\ ${ }^{l} R \& D$ Headquarters, Korean Ginseng Cooperation, Daejeon 34520, Korea \\ ${ }^{2}$ College of Veterinary Medicine, Kyungpook National University, Daegu 41566 Korea
}

\begin{abstract}
This study was carried out to investigate the protective effect of crude saponin from Platycodon grandiflorum on Clinical chemical parameters in male rats acutely exposed to 2,3,7,8-tetrachlorodibenzo- $\rho$-dioxin (TCDD). Crude saponin was prepared from Korean Platycodon grandiflorum with Diaion HP-20 adsorption chromatography after extraction of $80 \%$ ethanol at $75^{\circ} \mathrm{C}$. The crude saponin was confirmed by thin layer chrmatography. When compared with ginseng saponins, the crude saponin had both a few number of saponins and a broad distribution. Forty male rats $(200 \pm 20$ g) were divided into 4 groups. Normal control (NC) group received vehicle and saline; TCDD-treated (TT) group received TCDD (40 $\mu \mathrm{g}$ / $\mathrm{kg}$, single dose) intraperitoneally; Platycodon grandiflorum saponin (PG5 and PG10) groups received crude saponin $5 \mathrm{mg} /$ $\mathrm{kg}$ and $10 \mathrm{mg} / \mathrm{kg}$ (p.o), respectively, for 2 weeks before 1 week of TCDD-exposure. Increase of body weight was retarded greatly by TCDD-exposure. Body weight of animals in TT group was significantly decrease after 2 days of TCDDexposure. However, body weights of animals in PG groups increased through the experimental perimental period, although the increasing rate was slower than that of NC group. Increases in contents of blood glucose, total cholesterol and triglyceride (TG) and activities of amylase, lipase, AST, ALT and LDH by toxic action of TCDD were significantly attenuated by crude saponin from Platycodon grandiflorum $(P<0.05)$. In conclusion, these results suggest that crude saponin prepared from Korean Platycodon grandiflorum might be a member of useful protective agents against TCDD, which is one of the environmental hormones.
\end{abstract}

Key Words: 2,3,7,8-Tetrachlorodibenzo- $\rho$-dioxin, Saponins, Platycodon grandiflorum, Rats

\section{서 론}

도라지(Platycodon grandiflorum Nakai)는 길경(桔梗, Platycodi Radix)이라고도 불리며, 초롱꽃과(Campanulaceae) 식물로 한국, 일본 및 중국의 산간지방에 널리 자생한다. 여러해살이 풀로 7 8월에 종 모양의 흰색 또는 자주색
꽃이 피며 뿌리는 먹거나 거담이나 진해의 약재로도 이 용된다(Lim, 1971). 도라지는 예로부터 약재로 쓰여 왔기 때문에 지금까지 다양한 연구를 통해 그 효능이 속속 밝 혀지고 있다. 한방에서는 배농, 거담, 기관지염 및 천식 등의 호흡기계통 질환에 사용되어온 생약재로서 방약합 편에 49건, 동의보감에 287건의 처방에 빈용되는 생약으 로 약용보다는 식용으로 더 많이 이용되어 왔다(Jeong and

Received: April 22, 2020 / Revised: June 23, 2020 / Accepted: June 23, 2020

${ }^{*}$ Researcher, ${ }^{* *}$ Professor.

${ }^{\dagger}$ Corresponding author: Man Hee Rhee. College of Veterinary Medicine, Kyungpook National University, Daegu 41566, Korea.

Tel: +82-53-950-5967, Fax:+82-53-950-5955, e-mail: rheemh@knu.ac.kr

(C) The Korean Society for Biomedical Laboratory Sciences. All rights reserved.

(C) This is an Open Access article distributed under the terms of the Creative Commons Attribution Non-Commercial License (http://creativecommons.org/licenses/by-nc/3.0/) which permits unrestricted non-commercial use, distribution, and reproduction in any medium, provided the original work is properly cited. 
Shim 2006). 도라지(桔梗)의 열수 및 메탄올추출물은 암세 포 접착저해 및 면역 약리효과가 있다고 보고되었으며 (Kim et al., 1998), 간세포에 t-butyl hydroperoxide로 유발한 산화적 스트레스에 대해 도라지 열수추출물이 간세포를 보호한다는 연구결과도 있다(Choi et al., 2002). 또한 항콜 린작용, 혈당강하 작용, 콜레스테롤 대사 개선작용 등도 보고되고～있다(Lee, 1974; Seo et al., 2004; Kim et al., 1995).

도라지의 화학성분으로는 inulin 및 fructo-oligosaccride 등 탄수화물이 전체의 90 95\% 이상을 차지한다(Oka et al., 1992). 이 밖에도 platycodigenin, polygalacic acid 등 oleanane 계 triteripene을 aglycone으로 한 20여 종의 사포닌들이 $1 \sim 4 \%$ 정도 함유되어 있다. 이들 사포닌성분이 도라지추 출물의 주요한 활성성분 중의 하나로 알려져 있다(Ishii et al., 1981; Ishii et al., 1984; Saeki et al., 1999; Nikaido et al., 1999). 또한 도라지추출물의 열수추출물은 acetaminophen 에 의한 간손상을 유의적으로 억제한다고 보고되어 있으 며(Choi et al., 2001), 복강거식세포활성과 면역활성을 증 가시킨다는 연구결과도 있다(Lee and Jeong, 2002; Choi et al., 2001).

한편, TCDD (2,3,7,8-tetrachlorodibenzo- $\rho$-dioxin)는 polychlorinated aromatic hydrocarbon group에 속하는 다이옥신 계열의 화합물로서 동·식물의 내분비계를 교란시킨다고 하여 최근에는 내분비 교란성 화합물, 일명 환경호르몬으 로 널리 알려져 있다. 다이옥신은 쓰레기 소각장, 자동차 매연, 펄프 제지공장 등에서 배출되고 있으며 자연계에서 는 거의 분해되지 않으므로 식품순환계(food chain)을 타 고 계속 순환되는 것이 특징이다. 다이옥신 중 가장 맹독 성 화합물인 $\mathrm{TCDD}$ 는 생식독성, 간독성, 당뇨, 고지혈증, 체중감소, 성장억제, 암발생 등 매우 다양한 독성을 유발 하는 것으로 보고되고 있다(Matsumura et al., 1984). 근년의 다이옥신의 독성에 대한 생약재 연구에서 인삼은 다이옥 신에 의해 유발된 생식독성과 악화된 임상화학적 지수 및 세포조직학적 변화를 개선시킨다는 사실이 보고된 바 있 다(Kim et al., 1999; Kim et al., 2000; Kwak et al., 2006). 그러 나 그 밖의 생약재에 대해서는 연구된 바가 적고 도라지 의 경우에도 아직까지 보고되지 않았으므로 본 실험에서 는 인삼과 유사한 사포닌을 다량 함유하고 있는 도라지 의 환경호르몬에 대한 신규 생리활성효과를 연구하고자 하였다. 우선 도라지 중 활성성분으로 알려진 조사포닌 분획을 조제한 후 이를 다이옥신(TCDD)-독성이 유발된 흰쥐에 투여함으로써 환경호르몬 독성에 대한 방어효과 를 규명하고자 하였다.

\section{재료 및 방법}

\section{실험동물}

실험동물은 삼육실험동물 연구소(Oan City, Kyungi-Do, Korea)에서 구입한 흰쥐(Sprague Dawley rat, male, $200 \pm$ $20 \mathrm{~g}$ )를 적응을 위해 동물사육실에서 1주간 예비 사육한 다음 1 군을 10 마리씩 나누어 실험에 사용하였다. 실험동 물의 사육은 온도는 $23 \pm 1{ }^{\circ} \mathrm{C}$, 습도는 $40 \sim 60 \%$, 명암주기 는 12 시간의 조건으로 하였다. 사료는 일반 흰쥐용 고형 사료(SamYang Food Company, Korea)를 사용하였고 식수는 제한없이 공급하였다.

\section{도라지 사포닌 분획의 조제}

도라지는 농협(3년산, 강원도 횡성 태기산)으로부터 구 입하여 사용하였다. 도라지시료는 환류냉각관이 부착된 water bath $\left(80^{\circ} \mathrm{C}\right)$ 에서 5 8배 $(\mathrm{v} / \mathrm{w})$ 의 $80 \%$ 에탄올로 3 시간 동안 3회 반복하여 추출하였다. 추출액은 여과(Whatman $\mathrm{No} .41$ )하여 $70^{\circ} \mathrm{C}$ 이하에서 감압 및 농축한 후 인삼의 사 포닌 분리방법인 Diaion HP 수지흡착법에 준하여 조제하 였다(Kim et al., 1998). 좀더 자세히 설명하면 상기 환류추 출법으로 조제한 도라지 $80 \%$ 에탄올 농축액을 소량의 물 로 용해시킨 후 Diaion HP-20 수지(Mitsubish Casei, Japan) 가 흡착된 칼럼에 분주하였다. 1차적으로 4 5배(v/v)의 증 류수 및 $25 \%$ 에탄올을 가하여 도라지의 비사포닌 분획 을 제거한 후 연속적으로 4 5배(v/v)의 $95 \%$ 에탄올을 가 해 사포닌 분획을 용출하였다. 용출된 분획은 $70^{\circ} \mathrm{C}$ 이하 에서 감압 및 농축하고 동결건조를 행하여 목적하는 조 사포닌 분획을 조제하였다.

\section{도라지 조사포닌 분획의 TLC 분석}

도라지으로부터 분리된 사포닌의 특성은 통상의 인삼사 포닌 TLC 분석방법에 준하여 확인 및 분석하였다(Kwak et al., 2006). 즉, TLC plate (Silica gel $60 \mathrm{~F}_{254}$, Merck, Darmstadt, Germany)에 각 시료를 일정량 점적하여 $\mathrm{CHCl}_{3}: \mathrm{MeOH}$ : $\mathrm{H}_{2} \mathrm{O}$ (65:35:10, v/v, lower phase)을 전개용매로 전개한 후 $30 \% \mathrm{H}_{2} \mathrm{SO}_{4}$ 용액으로 발색시켜 $110^{\circ} \mathrm{C}$, dry oven에서 사포 닌 발색점를 확인하였다.

\section{TCDD 및 도라지 조사포닌 분획 투여}

TCDD는 AccuStandard Inc. (New Haven, CT, USA)으로 부터 순도 $>99.1 \%$ (gas chromatography 분석)를 구입한 후 


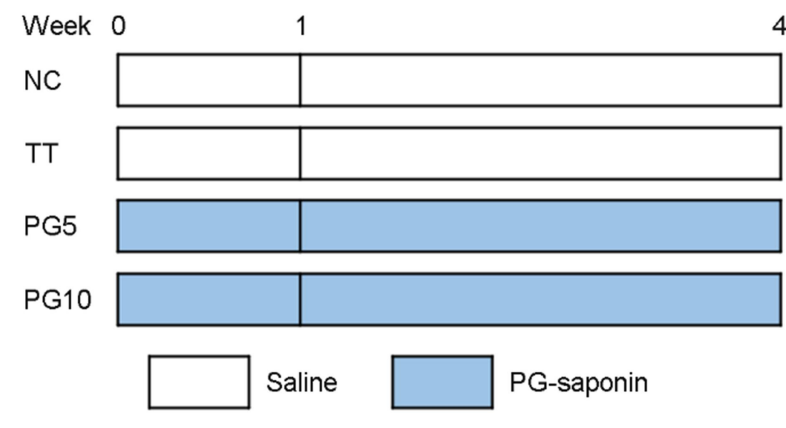

Fig. 1. Protocol for the treatment of TCDD and crude saponin from Platycodon grandiflorum. Normal control (NC group) rats received vehicle (corn oil and small amount of acetone containing trace amount of dimethylsulfoxide) and saline. TCDD-treated (TT group) rats received TCDD and saline. Saponin from Platycodon grandiflorum was p.o. administered before 1 week TCDD-exposure with a dose of $5 \mathrm{mg} / \mathrm{kg}$ (PG5 group) and $10 \mathrm{mg} / \mathrm{kg}$ (PG10 group). Each group consists of 10 male rats. TCDD was injected (i.p.) at the first week of the experiment at a single dose of $40 \mu \mathrm{g} / \mathrm{kg}$,b.w. Crude saponin from Platycodon grandiflorum was adminstered at daily dose of $5 \mathrm{mg} / \mathrm{kg}$ or $10 \mathrm{mg} / \mathrm{kg}$ for 4 weeks, respectively.

Kim 등(Kim et al., 2000)의 방법에 준하여 소량의 DMSO, acetone 및 corn oil에 희석하여 제조하였다. TCDD 및 시 료의 투여는 Fig. 1에 나타낸 바와같이 정상대조군(NC)에 대해서는 TCDD 운반체[미량의 DMSO $(50 \mu \mathrm{L})$ 와 소량의 acetone $(450 \mu \mathrm{L})$ 을 함유한 corn oil $(4.5 \mathrm{~mL})$ 을 투여하였고, $\mathrm{TCDD}$ 단독투여군(TT)에 대해서는 TCDD $(40 \mu \mathrm{g} / \mathrm{kg}$, single dose, i.p.)을 투여하였다. 한편 도라지 사포닌 $5 \mathrm{mg}$ 투여군 (PG5) 및 $10 \mathrm{mg}$ 투여군(PG10)은 TCDD 투여 7일 전부터 4주간 경구로 투여하였으며 NC 및 TT군에 대해서는 생 리식염수를 투여하였다. 모든 동물실험은 한국인삼공사 R\&D 본부 실험동물윤리위원회의 승인(KT\&G-13-001)을 받았으며 실험동물윤리를 준수하여 수행하였다.

\section{실험기기}

혈액학적 검사를 위해서는 혈액자동분석기(SysmaxNE8000, TOA medical Japan)를, 임상화학적 검사를 위해서는 임상화학자동분석기(Hitachi-7150, Hitachi Medical, Japan) 를 사용하여 실시하였다. 전해질 검사는 전해질분석기 (AVL9180 Electrolyte Analyzer, Roche, Swiss)를 사용하여 통 상의 임상생리학적 실험방법에 준하여 실시하였다.

\section{통계처리}

모든 실험결과는 mean \pm S.D.로 표기하였으며 정상대조 군(NC)과 TCDD 단독투여군(TT) 및 도라지 사포닌 투여

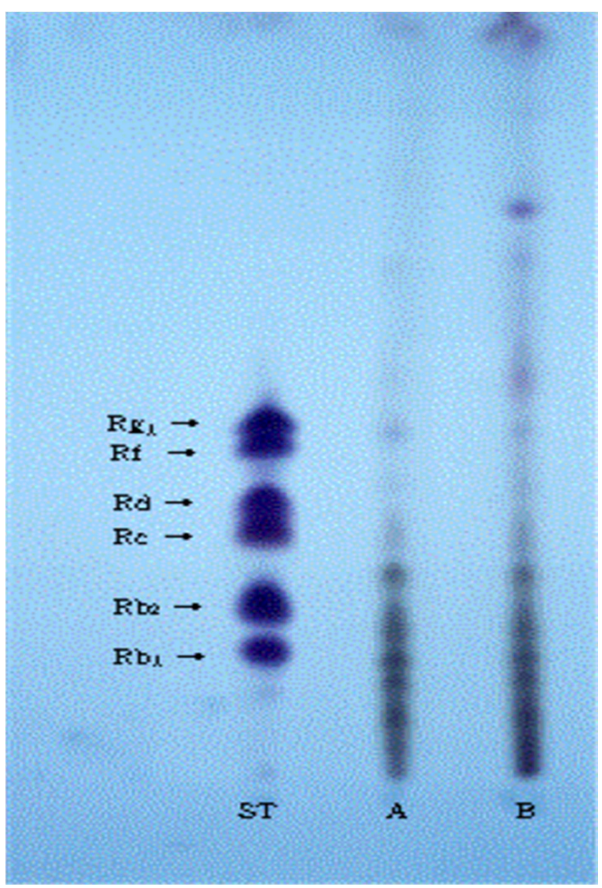

Fig. 2. TLC patterns of saponin fractions isolated from Platycodon grandiflorum. Each sample was added to TLC silica gel plate in a certain amount and was developed with a developing solvent, and then developed with $30 \% \mathrm{H}_{2} \mathrm{SO}_{4}$ solution. The saponin spot was confirmed in a dry oven at $110^{\circ} \mathrm{C}$. ${ }^{*} \mathrm{ST}$ : Standard of ginseng saponins, A: Saponin fraction from water extract of Platycodon grandiflorum, B: Saponin fraction from $80 \%$ ethanol extract of Platycodon grandiflorum.

군(PG5, PG10)과의 비교는 Graphpad Prism version 7.00 (San Diego, CA, USA)와 one-way ANOVA with Dunnett's post test 를 사용하여 통계분석하였다.

\section{결과 및 고찰}

\section{도라지 조사포닌 분획의 조제}

도라지 사포닌의 분자량 및 화합물 특성이 인삼사포닌 과 유사한 aglycone 구조를 가지므로 본 실험에서는 인공 합성수지를 이용한 인삼 조사포닌 분리법에 준하여 도라 지 조사포닌 분획을 조제하였다(Kim et al., 1998). 도라지 조사포닌의 TLC로 분석결과는 Fig. 2 에서 보는 바와 같다. 도라지뿌리 부분에는 platycodin $\mathrm{A}, \mathrm{C}, \mathrm{D}$ 와 polygalacin $\mathrm{D}$ 등 20 여종의 사포닌이 존재하는 것으로 알려져 있다(Ishii et al., 1981; Ishii et al., 1984). 본 실험에서 도라지 조사포닌 분 획은 인삼의 주종사포닌(major saponin)인 ginsenoside-Rb1, $-\mathrm{Rb} 2,-\mathrm{Rc},-\mathrm{Rd},-\mathrm{Re},-\mathrm{Rg} 1$ 과는 다른 $\mathrm{Rf}$ 치를 보여주었다. 또 


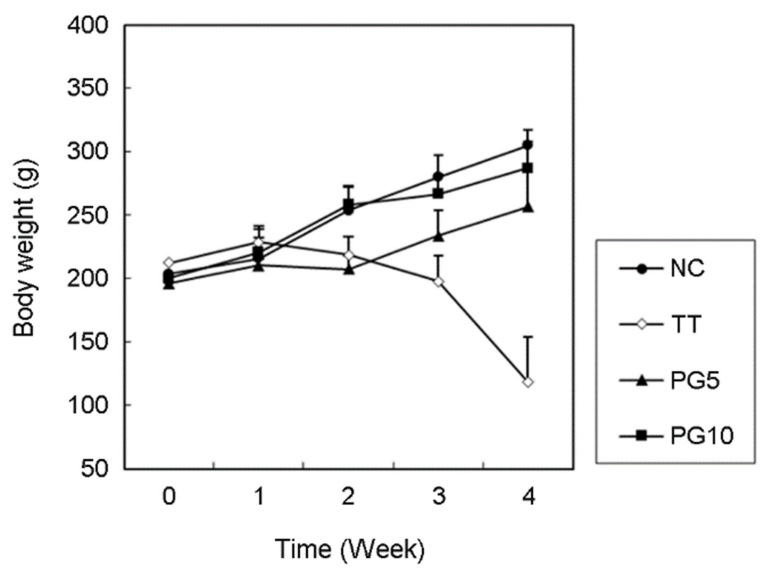

Fig. 3. Effect of crude saponin from Platycodon grandiflorum on body weight changes in male rats exposed to TCDD.

한 도라지 물추출물과 알코올추출물로부터 각각의 도라 지 사포닌을 조제하여 TLC로 비교한 결과는 알코올추출 물에서 다수의 비극성 사포닌을 볼 수 있었다. 일반적으 로 Rf 치가 낮을 수록 극성을 띠고, 높을수록 비극성을 띤다고 볼 때 도라지 사포닌은 인삼사포닌과 달리 비극 성보다는 극성 화합물이 다량 함유되어 있는 것으로 생 각되어진다. 또한 도라지 사포닌은 인삼 사포닌보다 극 성사포닌이 다수 함유되어 있었으며 특히, 진세노사이드 $-\mathrm{Rb} 1$ 이외의 극성사포닌 분포가 높았다. 이러한 극성사포 닌에 대해서는 추후 순수분리를 통한 성분규명 연구가 필요하다 하겠다.

\section{흰쥐의 체중변화에 미치는 영향}

흰쥐의 체중은 TCDD 투여 2주일 후부터 급격히 감소 하기 시작하여 투여 3 주 때에는 사망에 이르지는 않았지 만 무게가 초기 $200 \mathrm{~g}$ 에서 약 $100 \mathrm{~g}$ 으로 크게 감소되었다. $\mathrm{TCDD}$ 투여 시 체중감소는 외형적으로 가장 현저하게 나 타나는 현상으로 성장기 동물의 체중이 거의 증가하지 않은 것이 특징이다. 또한 시간이 경과할 수록 체중은 오 히려 감소하여 결국 죽게 된다고 알려져 있다. 본 실험 에서도 TCDD 단독투여군의 체중은 현저히 감소하였다 (Fig. 3). 그러나 도라지 조사포닌 투여군(PG5 및 PG10)은 $\mathrm{TCDD}$ 투여 1 주일 전부터 전투여 하였고, TCDD 투여한 이후에는 TCDD 단독투여군(TT)에 비해 체중감소가 크게 억제되었다. 도라지 조사포닌 투여군의 경우는 정상대조 군 $(\mathrm{NC})$ 에 비해 체중증가가 다소 둔화되었지만 $\mathrm{TT}$ 군에 비해서는 체중감소에 큰 방어효과를 나타내었다. 즉, 고
용량 투여군(PG10)의 경우가 저용량(PG5)보다 더 효과가 있는 것으로 나타났다. 그러나 투여 용량별 체중변화는 통계적 유의성이 관찰되지 않았다. 이러한 결과는 조사포 닌 사포닌 추출물이 $\mathrm{TCDD}$ 에 의해 야기되는 체중감소를 억제한다는 사실을 시사한다. $\mathrm{TCDD}$ 에 의한 감수성은 동 물의 종에 따라 차이가 있으나 일반적으로 $\mathrm{TCDD}$ 에 노출 된 동물의 사망 시 체중은 정상동물의 약 $50 \%$ 에 달하며 (Poland and Knutson, 1982), 그 원인으로는 glucose transport 저하 및 지방세포(adipocyte)에 존재하는 LPL (lipoprotein lipase)의 활성저하 등이 원인으로 알려져 있다(Brewster and Matsumura, 1989). 또한 LPL의 활성저하는 protein kinase $\mathrm{C}$, tyrosine kinase 등과 같은 각종 protein kinase kinase activity 활성증가에 기인하는 것으로 보고되고 있다 (Enan et al., 1992). 한편 홍삼은 lypolysis를 억제함으로써 당뇨병환자의 체중감소를 억제하고 지방합성을 촉진하 며 $\mathrm{TCDD}$ 에 의한 체중감소를 억제한다고 보고한 바 있다 (Kim et al., 2000). 본 실험에서도 도라지 사포닌이 TCDD 에 의한 체중감소를 억제하는 것으로 나타났다. 이는 도 라지에서 분리한 사포닌이 홍삼사포닌과 사포닌 패턴과 함량은 차이가 있지만 유사 구조의 사포닌 화합물(Ishii et al., 1981)이라는 사실을 고려하면 도라지의 TCDD 체중감 소 독성억제 작용의 주요한 활성성분은 도라지 사포닌 성 분일 것으로 추정해 볼 수 있겠다.

\section{장기무게 변화에 미치는 영향}

$\mathrm{TCDD}$ 투여가 장기무게 변화에 미치는 영향을 조사하 였다(Table 1). 간의 무게는 정상대조군 $10.48 \pm 0.74 \mathrm{~g}$ 에서 $\mathrm{TCDD}$ 투여군(TT)에서는 $7.82 \pm 1.50 \mathrm{~g}$ 으로 $25.4 \%$ 감소하 였으나 $(P<0.05)$, 도라지 조사포닌 투여군(PG5, PG10)에서 는 $10.10 \pm 2.00$ 및 $10.35 \pm 1.69 \mathrm{~g}$ 으로 각각 $3.6 \%$ 및 $1.2 \%$ 감소에 그쳐 $\mathrm{TCDD}$ 에 의한 간무게 감소를 유의적으로 억 제하였다 $(P<0.01)$. Testis(고환) 무게도 정상대조군의 3.45 $\pm 0.30 \mathrm{~g}$ 에서 $\mathrm{TCDD}$ 투여군에서는 $3.00 \pm 0.39 \mathrm{~g}$ 으로 $13.0 \%$ 감소하였다. 반면 도라지 조사포닌 투여군(PG5, PG10)에 서는 각각 $3.30 \pm 0.12$ 및 $3.35 \pm 0.18 \mathrm{~g}$ 으로 정상대조군 수 준으로 유의적으로 회복되는 경향을 나타내었다 $(P<0.05$, $P<0.01$ ). Spleen(비장)의 무게도 TCDD 투여에 의해 정상 대조군 대비 $43.5 \%$ 감소하였으나 도라지 조사포닌 투여 군(PG5, 10)에서는 각각 $27.1 \%$ 및 $18.8 \%$ 감소에 그쳐 비 장의 무게감소를 억제하는 경향을 나타내었다. Kidney(신 장)의 경우에는 $\mathrm{TCDD}$ 투여군(TT)과 도라지 조사포닌 투 여군(PG5, PG10)간에는 큰 차이가 관찰되지 않았다. 일련 
Table 1. Effect of crude saponin from Platycodon grandiflorum on organ weights in male rats exposed to TCDD

\begin{tabular}{ccccc}
\hline \hline Group $(\mathrm{n}=10)$ & Testis $(\mathrm{g})$ & Liver $(\mathrm{g})$ & Kidney $(\mathrm{g})$ & Spleen $(\mathrm{g})$ \\
\hline NC & $3.45 \pm 0.30$ & $10.48 \pm 0.74$ & $2.15 \pm 0.26$ & $0.80 \pm 0.20$ \\
TT & $3.00 \pm 0.39^{*}$ & $7.82 \pm 1.50^{\# \#}$ & $2.14 \pm 0.17$ & $0.49 \pm 0.15^{* *}$ \\
PG5 & $3.30 \pm 0.12^{\#}$ & $10.10 \pm 2.00^{* * *}$ & $2.20 \pm 0.30$ & $0.62 \pm 0.10$ \\
PG10 & $3.35 \pm 0.18^{\# \#}$ & $10.35 \pm 1.69^{* * *}$ & $2.19 \pm 0.20$ & $0.70 \pm 0.17$ \\
\hline
\end{tabular}

Data were presented as mean \pm SD. ${ }^{\#}$ indicates $P<0.05,{ }^{\#}$ indicates $P<0.01,{ }^{\# \#}$ indicates $P<0.001$ as compared to NC, whereas ${ }^{*}$ indicates $P<0.05,{ }^{* *}$ indicates $P<0.01,{ }^{* * *}$ indicates $P<0.001$ as compared to TT. Note on group ${ }^{1)}$ designations are the same as in Fig. 1

Table 2. Effect of crude saponin from Platycodon grandiflorum on blood hematologic parameters in male rats exposed to TCDD

\begin{tabular}{|c|c|c|c|c|c|}
\hline Group $(\mathrm{n}=10)$ & WBC $\left(10^{3} / \mu \mathrm{L}\right)$ & $\mathrm{RBC}\left(10^{6} / \mu \mathrm{L}\right)$ & Н НCT (\%) & HGB (g/dL) & PLT $\left(10^{3} / \mu \mathrm{L}\right)$ \\
\hline $\mathrm{NC}$ & $9.18 \pm 3.10$ & $6.45 \pm 1.66$ & $31.84 \pm 8.42$ & $11.07 \pm 3.50$ & $722.30 \pm 103.13$ \\
\hline $\mathrm{TT}$ & $33.88 \pm 23.98$ & $8.05 \pm 1.79$ & $40.45 \pm 4.00$ & $15.87 \pm 1.50$ & $289.25 \pm 124.05^{\# \# \# ~}$ \\
\hline PG5 & $18.34 \pm 3.22$ & $7.10 \pm 1.01$ & $38.02 \pm 3.35$ & $14.70 \pm 0.80$ & $641.00 \pm 50.08^{* * *}$ \\
\hline PG10 & $17.10 \pm 5.10$ & $6.90 \pm 0.99$ & $38.27 \pm 2.45$ & $14.44 \pm 0.71$ & $684.70 \pm 105.12^{* * *}$ \\
\hline
\end{tabular}

Data were presented as mean $\pm \mathrm{SD} .{ }^{\# \#}$ indicates $P<0.001$ as compared to NC, whereas ${ }^{* * *}$ indicates $P<0.001$ as compared to TT. Note on group designations are the same as in Fig. 1. WBC: white blood cell, RBC: red blood cell, HCT: hematocrit, HGB: hemoglobin, PLT: platelet

의 $\mathrm{TCDD}$ 에 대한 홍삼사포닌의 방어효과 연구를 살펴보 면(Kim et al., 2000; Kwak et al., 2006), 홍삼농축액으로부터 홍삼사포닌을 분리하여 Guinea pig을 이용한 동물 실험 결과 사포닌은 $\mathrm{TCDD}$ 에 의해 감소된 고환무게를 회복시 킨다고 보고하였다. 또한 흰쥐를 이용한 실험결과에서도 $\mathrm{TCDD}$ 에 의해 감소된 고환무게를 홍삼사포닌이 회복시킨 다고 보고한 바 있다. 본 실험에서도 홍삼사포닌과 유사 한 결과를 보이며 이러한 결과로부터 도라지 조사포닌은 $\mathrm{TCDD}$ 와 같은 환경호르몬에 의한 생식독성을 방어하는 하나의 성분으로 생각해 볼 수 있겠다.

\section{일반 혈액 생리화학적 변화에 미치는 영향}

$\mathrm{WBC}$ (백혈구수)는 TCDD 투여에 의해 정상군 대비 $369.0 \%$ 로 크게 증가하였으나 도라지 조사포닌 투여군 (PG5)은 증가율이 $99.8 \%$ 이었고, 투여군(PG10)은 증가율이 $86.3 \%$ 로 백혈구수 증가율이 $\mathrm{TCDD}$ 단독투여군(TT군)에 비해 현저히 억제되었다. 그러나 투여군간 유의적 차이는 없었고 용량 의존성도 관찰되지 않았다. 적혈구 $(\mathrm{RBC}, \mathrm{red}$ blood cell)도 TCDD 투여군에서 $24.8 \%$ 증가한 반면 도라 지 사포닌 투여군(PG5, 10)에서는 각각 $10.1 \%$ 및 $7.0 \%$ 증 가에 그쳐 $\mathrm{TCDD}$ 에 의한 적혈구수 증가도 억제하였다. 혈소판(PLT, platelet)는 TCDD 투여에 의해 정상군 대비 $60.0 \%$ 감소하였다. 그러나 도라지 사포닌투여군(PG5 및
$\mathrm{PG} 10$ )에 있어서는 각각 $11.3 \%$ 및 $5.2 \%$ 감소하여, $\mathrm{TCDD}$ 투여로 야기되는 혈소판수의 감소를 유의적으로 억제하 는 것으로 나타났다 $(P<0.05, P<0.01)$. 그 외의 항목 $\mathrm{HCT}$ (hematocrit) 및 HGB (hemoglobin) 함량에 있어서는 TCDD 투여군과 도라지 조사포닌 투여군(PG5, PG10)간 큰 차이 가 관찰되지 않아서 효과가 없는 것으로 생각된다(Table 2). $\mathrm{TCDD}$ 는 조혈장기에 작용하여 혈소판 및 백혈구 생성장 애를 야기시킨다고 알려져 있다(Poland and Knutson, 1982). 일련의 웅성 기니픽을 이용한 실험결과에서도 $\mathrm{TCDD}$ 투 여 시 감소된 혈소판수를 홍삼물추출물은 유의적으로 경 감시킨다고 보고한 바 있다(Kim et al., 2000). 흰쥐를 사용 한 실험에서도 홍삼사포닌이 $\mathrm{TCDD}$ 에 의해 감소된 혈 소판수를 용량의존적으로 회복시킨다고 보고한 바 있다 (Kwak et al., 2006). 도라지에서 분리한 조사포닌을 이용한 본 실험에서도 감소된 혈소판수를 억제시켜 방어효과가 있는 것으로 나타났다.

\section{지질 및 당관련 임상화학지수에 미치는 영향}

알려진 바와 같이 TCDD 투여는 혈중 지질 함량의 현 저한 증가를 초래한다. 정상대조군 $(\mathrm{NC})$ 의 $\mathrm{TC}$ (total cholesterol) 함량은 $50.30 \pm 5.44 \mathrm{mg} / \mathrm{dL}$ 에서 TCDD 투여군(TT군) 은 $113.70 \pm 58.20 \mathrm{mg} / \mathrm{dL}$ 로 정상대조군 대비 $126.0 \%$ 증가하 였다(Table 3). 반면 도라지 조사포닌 투여군(PG5, PG10)은 
Table 3. Effect of crude saponin from Platycodon grandiflorum on lipid and glucose metabolism related parameters in male rats exposed to TCDD

\begin{tabular}{ccccccc}
\hline \hline $\begin{array}{c}\text { Group } \\
(\mathrm{n}=10)\end{array}$ & $\begin{array}{c}\text { Triglyceride } \\
(\mathrm{mg} / \mathrm{dL})\end{array}$ & $\begin{array}{c}\text { T.C. } \\
(\mathrm{mg} / \mathrm{dL})\end{array}$ & $\begin{array}{c}\text { LDL-C } \\
(\mathrm{mg} / \mathrm{dL})\end{array}$ & $\begin{array}{c}\text { HDL-C } \\
(\mathrm{mg} / \mathrm{dL})\end{array}$ & \multicolumn{1}{c}{$\begin{array}{c}\text { Glucose } \\
(\mathrm{mg} / \mathrm{dL})\end{array}$} & $\begin{array}{c}\text { Amylase } \\
(\mathrm{IU} / \mathrm{L})\end{array}$ \\
\hline NC & $70.27 \pm 18.40$ & $50.30 \pm 5.44$ & $2.95 \pm 1.50$ & $37.10 \pm 4.32$ & $160.40 \pm 17.83$ & $5,117.00 \pm 480.10$ \\
TT & $92.47 \pm 42.70$ & $113.70 \pm 58.20$ & $13.80 \pm 5.80$ & $41.00 \pm 18.59$ & $92.23 \pm 35.02$ & $2,820.82 \pm 398.59^{m \ldots}$ \\
PG5 & $87.12 \pm 39.66$ & $69.43 \pm 20.18$ & $6.70 \pm 4.45$ & $42.23 \pm 11.55$ & $133.57 \pm 18.60$ & $4,542.43 \pm 853.30^{* * *}$ \\
PG10 & $76.30 \pm 36.30$ & $66.47 \pm 17.30$ & $6.50 \pm 4.40$ & $40.30 \pm 8.88$ & $150.00 \pm 30.72$ & $4,689.30 \pm 965.55^{* * *}$ \\
\hline
\end{tabular}

${ }^{\# \#}$ indicates $P<0.001$ as compared to NC, whereas ${ }^{* * *}$ indicates $P<0.001$ as compared to TT. Note on group designations are the same as in Fig. 1. T.C: total cholesterol, LDL-C: low density lipoprotein cholesterol, HDL-C: highdensity lipoprotein cholesterol. The values are expressed as mean \pm S.D.

$69.43 \pm 20.18$ 및 $66.47 \pm 17.30 \mathrm{mg} / \mathrm{dL}$ 로 각각 38.0 및 $32.1 \%$ 증가에 그쳐 $\mathrm{TCDD}$ 에 의한 cholesterol의 증가를 억제하는 것으로 나타났다. LDL-C (low density lipoprotein cholesterol) 함량도 TCDD 단독투여군(TT)은 정상대조군 대비 $367.8 \%$ 증가하였으나 도라지 조사포닌 투여군(PG5, PG10)은 각각 $127.1 \%$ 및 $120.3 \%$ 증가에 그쳐 함량증가를 억제하였다. HDL-C (high density lipoprotein cholesterol) 함량은 큰 차이 가 관찰되지 않았다. 중성지방 Triglyceride (TG) 함량은 정 상대조군에서는 $70.27 \pm 18.40 \mathrm{mg} / \mathrm{dL}$ 이었으나 TT군에서는 $92.47 \pm 42.70 \mathrm{mg} / \mathrm{dL}$ 로 $31.6 \%$ 증가하였다. 도라지 사포닌 투여군(PG5, PG10)에서는 87.12 \pm 39.66 및 $76.30 \pm 36.30 \mathrm{mg} /$ $\mathrm{dL}$ 로 각각 $24.0 \%$ 및 $8.6 \%$ 증가에 그쳐 $\mathrm{TCDD}$ 투여에 의 한 TG 함량증가를 억제하였다. TCDD 투여에 의해 정상대 조군 대비 $42.4 \%$ 감소된 glucose 함량은 도라지 사포닌 투 여군(PG5, $\mathrm{PG} 10)$ 에서는 각각 $16.7 \%$ 및 $6.5 \%$ 감소에 그쳐 함량감소를 어느 정도 억제하는 것으로 나타났다. TCDD 투여에 의해 정상대조군 대비 $44.9 \%$ 감소된 amylase 활성 도 도라지 조사포닌 투여군(PG5, PG10)에서 각각 $11.2 \%$ 및 $8.4 \%$ 감소에 그쳐 함량감소를 억제하는 경향을 나타 내었다. 그러나 amylase 이외 조사한 모든 항목에서는 통 계적 유의성은 관찰되지 않았다.

$\mathrm{TCDD}$ 의 투여는 guinea pig 및 흰쥐(rat)에 있어 혈중 중 성지방(triglyceride, TG) 및 총 콜레스테롤(total cholesterol, $\mathrm{TC})$ 의 현저한 증가를 초래한다고 보고된 바 있다(Poland and Knutson, 1982). 이와 같이 TCDD 독성유도 시 모든 동 물에서 공통적으로 나타나는 특징 중의 하나가 고지혈증 (hyperlipidemia)이며, 실험동물의 혈청에서 $\mathrm{TG}$ 및 $\mathrm{TC}$ 의 함량이 증가한다고 보고된 바 있다(Bombick et al., 1984; Brewster and Matsumura, 1989; Enan et al., 1992). 인삼의 경 우에는 사포닌성분이 혈중 콜레스테롤 저하와 고콜레스 테롤혈증으로 야기되는 혈관의 병변을 예방하는 효과가
있다고 알려진 바 있다(Yoon and Joo, 1993). 인삼사포닌 의 작용기전은 간장 내 콜레스테롤 대사항진과 이들 콜 레스테롤 운반물질 수용체(LDL-cholesterol receptor)의 활성 화 작용 및 혈중 지단백질 가수분해효소(LPL) 활성증가 작용이 관련 있는 것으로 알려져 있다(Bombick et al., 1984). 도라지 조사포닌의 경우 이에 관해서는 그다지 연 구가 되어 있지 않으므로 추후 이에 대한 추가적인 연구 가 필요할 것으로 생각된다.

\section{심장 및 신장관련 임상화학지수에 미치는 영향}

$\mathrm{TCDD}$ 투여에 의해 심장관련 생화학지수인 CK (creatinine kinase) 활성은 정상대조군 245.12 $\pm 86.02 \mathrm{IU} / \mathrm{L}$ 에서 TT군에서는 $89.33 \pm 79.78 \mathrm{IU} / \mathrm{L}$ 로 $63.6 \%$ 감소하였으며 도 라지 조사포닌 투여군(PG5, 10)에서는 각각 함량이 199.23 \pm 82.20 및 $200.57 \pm 90.87 \mathrm{IU} / \mathrm{L}$ 로 정상군 대비 $18.7 \%$ 및 $18.2 \%$ 감소에 그쳐 활성증가를 억제하여 회복효과를 나 타내었다. CRE (creatinine) 함량은 정상대조군 $0.62 \pm 0.10$ $\mathrm{IU} / \mathrm{L}$ 에서 TT군에서는 $0.38 \pm 0.14 \mathrm{IU} / \mathrm{L}$ 로 $38.7 \%$ 감소하였으 며 도라지 조사포닌 투여군(PG5, PG10)에서는 각각 함량 이 $0.58 \pm 0.21$ 및 $0.57 \pm 0.29 \mathrm{IU} / \mathrm{L}$ 로 정상군 대비 $6.5 \%$ 및 $8.1 \%$ 감소에 그쳐 함량증가를 억제하는 효과를 나타내었 다. BUN (blood urea nitrogen) 함량은 정상대조군 20.35 $1.88 \mathrm{IU} / \mathrm{L}$ 에서 $\mathrm{TT}$ 군에서는 $26.33 \pm 5.06 \mathrm{IU} / \mathrm{L}$ 로 $29.4 \%$ 증 가하였으며 도라지 조사포닌 투여군(PG5, 10)에서는 각 각 함량이 $19.00 \pm 2.81$ 및 $19.61 \pm 3.70 \mathrm{IU} / \mathrm{L}$ 로 정상군 대비 $6.6 \%$ 및 $3.6 \%$ 감소하여 함량증가를 억제하는 효과를 나 타내었다. 반면 TCDD 투여로 감소된 LDH (lactate dehydrogenase) 활성 및 UA (uric acid) 함량은 도라지 조사포닌 투여로 큰 변화가 관찰되지 않았다(Table 4).

신장은 생체의 대사과정에서 생긴 불필요한 노폐물을 체외로 배설시키고 체액의 전해질 및 $\mathrm{pH}$ 조절을 통하여 
신체의 항상성을 유지시키는 중요한 역할을 담당하고 있 다. 신장독성을 일으키는 물질은 매우 다양하며, 그 독성 의 양상 또한 동물에 따라 차이가 있다고 알려져 있다 (Poland and Knutson, 1982). 아직 명확하게 그 기전이 밝혀 지지 않았으나 신장이 독성물질의 표적이 되는 것은 노폐 물을 여과하는 과정에서 혈액에 함유된 독성물질에 그 만 큼 노출될 기회가 높고 일시적으로 저장되는 동안 독성물 질의 농축이 일어나기 때문이라고 사료된다. 한편 TCDD 는 지방조직에 침착되는 특성을 가지고 있으므로 지방조 직에 둘러싸여 있는 신장이 다이옥신에 의하여 심하게 손상을 받는 것으로 생각된다. 인삼의 경우에는 동물실험 에서 홍삼사포닌이 신장기능과 관련된 각종 임상화학지
수의 악화를 개선시킨다고 보고하였다(Kwak et al., 2006). 본 실험에서도 도라지 조사포닌이 $\mathrm{TCDD}$ 에 의해 야기되 는 신장독성을 경감시키는 것으로 사료된다.

\section{간기능 관련 생화학지수에 미치는 영향}

AST 활성 및 Albumin 함량은 TCDD 투여로 증가하는 경향을 나타내었다. $\mathrm{AST}$ 활성은 $\mathrm{TCDD}$ 투여로 정상대조 군 $130.70 \pm 16.10 \mathrm{IU} / \mathrm{L}$ 에서 $610.23 \pm 70.38 \mathrm{IU} / \mathrm{L}$ 로 $366.9 \%$ 큰 폭으로 증가하였으나 도라지 조사포닌 투여군(PG5, PG10) 에서는 $174.50 \pm 16.51$ 및 $180.11 \pm 90.71 \mathrm{IU} / \mathrm{L}$ 로 각각 정상군 대비 $33.5 \%$ 및 $37.8 \%$ 증가에 그쳐 회복되는 것으로 나타 났다. 그러나 TCDD 투여에 의해 $49.5 \%$ 감소된 ALT 활

Table 4. Effect of crude saponin from Platycodon grandiflorum on cardiac renal function parameters and LDH value in male rats exposed to TCDD

\begin{tabular}{cccccc}
\hline \hline Group $(\mathrm{n}=10)$ & LDH $(\mathrm{IU} / \mathrm{L})$ & CK $(\mathrm{IU} / \mathrm{L})$ & $\mathrm{CRE}(\mathrm{mg} / \mathrm{dL})$ & $\mathrm{BUN}(\mathrm{mg} / \mathrm{dL})$ & $\mathrm{UA}(\mathrm{mg} / \mathrm{dL})$ \\
\hline NC & $996.30 \pm 447.08$ & $245.12 \pm 86.02$ & $0.62 \pm 0.10$ & $20.35 \pm 1.88$ & $1.86 \pm 0.29$ \\
TT & $810.73 \pm 420.25$ & $89.33 \pm 79.78$ & $0.38 \pm 0.14$ & $26.33 \pm 5.06$ & $1.65 \pm 0.57$ \\
PG5 & $819.50 \pm 570.51$ & $199.23 \pm 82.20$ & $0.58 \pm 0.21$ & $19.00 \pm 2.81$ & $1.55 \pm 0.30$ \\
PG10 & $877.24 \pm 512.40$ & $200.57 \pm 90.87$ & $0.57 \pm 0.29$ & $19.61 \pm 3.70$ & $1.57 \pm 0.85$ \\
\hline
\end{tabular}

The values are expressed as mean \pm S.D. LDH: lactate dehydrogenase, CK: creatinine kinase, CRE: creatinine, BUN: blood urea nitrogen, UA: uric acid. Note on group designations are the same as in Fig. 1

Table 5. Effect of crude saponin from Platycodon grandiflorum on liver function realated parameters in male rats exposed to TCDD

\begin{tabular}{cccccc}
\hline \hline Group $(\mathrm{n}=10)$ & TP $(\mathrm{g} / \mathrm{dL})$ & Albumin $(\mathrm{g} / \mathrm{dL})$ & AST $(\mathrm{IU} / \mathrm{L})$ & ALT $(\mathrm{IU} / \mathrm{L})$ & ALP $(\mathrm{IU} / \mathrm{L})$ \\
\hline NC & $7.15 \pm 0.18$ & $3.26 \pm 0.21$ & $130.70 \pm 16.10$ & $138.10 \pm 51.01$ & $360.65 \pm 111.00$ \\
TT & $6.90 \pm 1.45$ & $4.20 \pm 2.20$ & $610.23 \pm 70.38^{\text {\#\# }}$ & $69.80 \pm 30.29$ & $352.05 \pm 165.10$ \\
PG5 & $8.02 \pm 0.56$ & $3.04 \pm 0.29$ & $174.50 \pm 16.51^{* * *}$ & $70.28 \pm 10.51$ & $360.17 \pm 130.12$ \\
PG10 & $7.90 \pm 0.44$ & $3.01 \pm 0.30$ & $180.11 \pm 90.71^{* * *}$ & $69.70 \pm 14.60$ & $351.57 \pm 102.44$ \\
\hline
\end{tabular}

\#\# indicates $P<0.001$ as compared to NC, whereas ${ }^{* * *}$ indicates $P<0.001$ as compared to TT. The values are expressed as mean \pm S.D. TP: total protein, AST: aspartate transferase, ALT: alanine amino-transferase, ALP: alkaline phosphatase. Note on group designations are the same as in Fig. 1

Table 6. Effect of crude saponin from Platycodon grandiflorum on inorganic ions of blood in male rats exposed to TCDD

\begin{tabular}{ccccc}
\hline \hline Group $(\mathrm{n}=10)$ & $\mathrm{Ca}^{2+}(\mathrm{mg} / \mathrm{dL})$ & $\mathrm{P}^{5+}(\mathrm{mg} / \mathrm{dL})$ & $\mathrm{Fe}^{2+}(\mathrm{mg} / \mathrm{dL})$ & $\mathrm{TIBC}(\mathrm{mg} / \mathrm{dL})$ \\
\hline NC & $16.60 \pm 1.87$ & $16.15 \pm 1.80$ & $96.28 \pm 40.78$ & $660.10 \pm 70.88$ \\
TT & $14.45 \pm 1.20$ & $10.52 \pm 2.50$ & $280.50 \pm 60.50^{\# \#}$ & $590.27 \pm 89.42^{\text {\#\# }}$ \\
PG5 & $14.01 \pm 1.12$ & $12.45 \pm 0.69$ & $279.17 \pm 80.14$ & $650.27 \pm 70.51^{*}$ \\
PG10 & $14.08 \pm 1.50$ & $12.35 \pm 1.60$ & $281.71 \pm 9.01$ & $659.29 \pm 99.21^{* *}$ \\
\hline
\end{tabular}

${ }^{\#}$ indicates $P<0.01,{ }^{\# \#}$ indicates $P<0.001$ as compared to NC, whereas ${ }^{*}$ indicates $P<0.05,{ }^{* *}$ indicates $P<0.01$ as compared to TT. The values are expressed as mean \pm S.D. TIBC: total iron binding capacity. The inorganic ions of blood were measured by AVL9180 Electrolyte Analyzer. Note on group designations are the same as in Fig. 1 
성은 도라지 조사포닌 투여(PG5, 10)에 의해 회복되지 않 는 것으로 나타났다. TP (total protein) 함량 및 ALP (alkaline phosphatase) 활성의 경우에는 큰 차이가 관찰되지 않았다 (Table 5). 홍삼사포닌 성분은 $\mathrm{TCDD}$ 에 의해 손상된 간기 능 활성을 회복시킨다고 보고한 바 있는데(Kwak et al., 2006), 도라지 조사포닌도 이와 유사하게 손상된 간기능 을 활성화 시키는 것으로 나타났다. 인삼 사포닌과 도라 지 조사포닌의 자세한 기전 차이 연구는 추후 연구를 계 속 진행해야 할 것으로 생각된다.

\section{혈액의 무기 이온에 미치는 영향}

$\mathrm{TCDD}$ 투여로 인해 흰쥐 혈액 중 $\mathrm{P}^{5+}$ 함량은 정상대조 군(NC) $16.15 \pm 1.80$ 에서 $10.52 \pm 2.50 \mathrm{mg} / \mathrm{dL}$ 로 $34.9 \%$ 감소 하였으며 도라지 조사포닌 투여군(PG5, PG10) 12.45 \pm 0.69 및 $12.35 \pm 1.60 \mathrm{mg} / \mathrm{dL}$ 로 정상대조군 대비 $22.9 \%, 23.5 \%$ 의 감소하여 일부 회복하였다. $\mathrm{Fe}^{2+}$ 함량은 정상대조군 $(\mathrm{NC})$ $96.28 \pm 40.78$ 에서 TT군에서 $280.50 \pm 60.50 \mathrm{mg} / \mathrm{dL}$ 로 $191.3 \%$ 상승하였으며 도라지 조사포닌 투여군(PG5, PG10)에서도 각각 $279.17 \pm 80.14$ 및 $281.71 \pm 9.01 \mathrm{mg} / \mathrm{dL}$ 로 정상대조군 대비 $190.0 \%, 192.6 \%$ 의 상승하여 도라지 사포닌의 효과는 없는 것으로 나타났다. TIBC (total iron binding capacity)은 $\mathrm{Fe}^{2+}$ 함량과 반대로 $\mathrm{TCDD}$ 투여에 의해 $10.6 \%$ 감소하였 는데, 도라지 조사포닌 투여군(PG5, PG10)에서는 정상대 조군 대비 각각 $1.5 \%, 0.1 \%$ 감소하는데 그쳐 회복되는 경 향을 나타내었으나 통계적인 유의성은 없었다. $\mathrm{Ca}^{2+}$ 함량 도 TCDD 투여로 TT군에서 감소하는 경향을 나타내었으 며 도라지 조사포닌 투여군도 역시 감소하여 통계적 유 의성은 관찰되지 않았다(Table 6).

\section{ACKNOWLEDGEMENT}

None.

\section{CONFLICT OF INTEREST}

The authors have no competing interests to declare.

\section{REFERENCES}

Bombick DW, Matsumura F, Madhukar B. TCDD (2,3,7,8tetrachlorodibenzo-p-dioxin) causes reduction in the low density lipoprotein*LDL) receptor activities in the hepatic plasma membrane of the guinea pig and rat. Biochemical and Biophysical Research Communications. 1984. 118: 548-554.
Brewster DW, Matsumura F. Differential effect of 2,3,7,8tetrachlorodibenzo-p-dioxin on adipose tissue tissue lipoprotein lipase activity in the guinea pig, rat, hamster, rabbit and mink Comparative Biochemistry and Physiology. Part C. Comparative Pharmacology. 1989. 93: 49-53.

Choi CY, Lee KJ, Jeong HG. Effects of aqueous extract isolated from Platycodon grandiforum against t-butyl hydroperoxide induced oxidative stress in rat primary hepatocytes. Yakhak Hoeji. 2002. 46: 466-471.

Choi CY, Kim JY, Kim YS, Chung YC, Seo JK, Jeong HG. Aqueous extract isolated from Platycodon grandiforum elicits release of nitric oxide and tumor necrosis factor-a from murine macrophages. International Immunopharmacology. 2001. 1: 1141 $-1151$.

Choi CY, Kim JY, Kim YS, Chung YC, Hahm KS, Jeong HG. Agumentation of macrophage functions by an aqueous extract isolated from Platycodon grandiflorum. Cancer Lett. 2001. 166: 17-25.

Enan E, Liu P, Matsumura F. 2,3,7,8-tetrachlorodibenzo-p-dioxin causes reduction of glucose transporting activities in the plasma membranes of adipose tissue and pancreas from the guinea pig. Journal of Biological Chemistry. 1992. 267: 19785 $-19791$.

Ishii H, Tori K, Tozyo T, Yoshimura Y. Saponins fromm roots of Platycodon grandiforum. Part. Structure of prosaponins. J.C.S. Perkin. 1981. 1: 1928-1933.

Ishii H, Tori K, Tozyo T, Yoshimura Y. saponins from roots of Platycodon grandiflorum. Part2. Isolation and structure of new triterpene glycosides. J.C.S. Perkin. 1984. 1: 661-668.

Jeong HJ, Shim KW. Chemical composition and antioxidative activities of Platycodon grandiforum leaves and stems. J Korean Soc Food Sci Nutr. 2006. 35: 511-515.

Kwak YS, Kyung JS, Song YB, Wee JJ, Park JD, Kim SK, Hwang MS, Kim SC, Park CK, Do JH. Protective effect of red ginseng saponin on decrease of femur weight in female guinea pigs acutely exposed to 2,3,7,8-tetrachlorodibenzo-p-dioxin (TCDD). Journal of Ginseng Research. 2006. 30: 112-116.

Kwak YS, Kyung JS, Song YB, Wee JJ, Park JD. Effect of crude saponin from red ginseng efflux on blood biochemical parameters in rats acutely exposed to 2,3,7,8-tetrachlorodibenzop-dioxin (TCDD). J Ginseng Res. 2006. 30: 8-14.

Kim YS, Lee BE, Kim KJ, Lee YT, Cho KB, Chung YC. Antitumor and immunomodulatory of the $P$. grandiforum cultivated for more than 20 years. Yakhak Hoeji. 1998. 42: 382-387. 
Kim KS, Osamu E, Shinji I, Hiroshige I. Effect of Platycodon grandiforum feeding on serum and liver lipid concentrations in rats with diet-induced hyperlipidemia. J Nutr Sci Vitaminol. 1995. 41: 485-491.

Kim SK, Kwak YS, Kim SW, Hwang SY, Ko YS, Yoo CM. Improved method for the preparation of crude ginseng saponin. J Ginseng Res. 1998. 22: 155-160.

Kim SK, Hwang SY, Wee JJ, Kwak YS, Kyung JS, Nam KY. Protective effect of crude saponin from Korean red ginseng on dioxin-induced testicular toxicity. The Ginseng Review. 2000. 28: 70-77.

Kim WJ, Hwang SY, Lee H, Song H, Kim SK. Panax ginseng protects the testis against 2,3,7,8-tetrachlorodibenzo-p-dioxin induced testicular damage in guinea pigs. BJU International. 1999. 83: 842-849.

Lee EB. Pharmacological studies of Platycodi Radix. Korean J Pharmacog. 1974. 5: 49-60.

Lee KJ, Jeong HG. Protective effect of Platycodi Radix on carbon tetrachlororide-induced hepatoxicity. Food Chem Toxicol. 2002. 40: 517-525.

Lim KH. A Medicinal Physiology. Dong Myoung Sa. Seoul. p281. 1971.

Matsumura F, Brewster DW, Madhukar BV, Bombick DW. Alteration of rat hepatic plasma membrane functions by $2,3,7,8$ tetrachloro-p-dioxin (TCDD). Arch Environ Contamation and Toxicology. 1984. 13: 509-515.

Nikaido T, Koike K, Mitsunagi KM, Saeki T. Two new triterpenoid saponins from Platycodon grandiflorum. Chem Pharm Bull. 1999. 47: 903-904.

Oka M, Ota N, Mino Y, Iwashita T, Komura H. Studies on the conformational aspects of inulin oligomers. Chem Pharm Bull. 1992. 40: 1203-1207.

Poland A, Knutson JC. 2,3,7,8-tetrachlorodibenzo- $\rho$-dioxin and related halogenated aromatic hydrocarbons: examnination of the mechanism of toxicity. Annual Review of Pharmacology and Toxicology. 1982. 22: 517-554.

Seo JK, Chung YC, Chun SS, Lee YY. Lee SJ, Shon MY, Sung NJ. Effect of physiologically active compounds isolated from Platycodon grandiforum on streptozotocin-induced diabetic rats. J Korean Soc Food Sci Nutr. 2004. 33:981-986.

Saeki T, Koike K, Nikaido T. A comparative study on commercial botanical gardens and wild samples of the roots of Platycodon grandifoflorum. Planta Med. 1999. 65: 428-431.

Yoon S, Joo C. Study on the preventive effect of ginsenosides against hypercholesterolesterolemia and its mechanism. Korean J Ginseng Sci. 1993. 17: 1-12.

https://doi.org/10.15616/BSL.2020.26.2.66

Cite this article as: Kwak YS, Moon YJ, Kyung JS, Kim TH, Rhee MH. Effect of Saponin Fraction from Platycodon grandiflorum on Clinical Chemical Changes in TCDD (2,3,7,8-Tetrachlorodibenzo- $\rho$-dioxin)-induced Rat Toxicity. Biomedical Science Letters. 2020. 26: 66-74. 